\title{
Lotman and cultural studies: The case for cross-fertilization
}

\author{
Andreas Schönle \\ Dept. of Slavic Languages and Literatures, University of Michigan \\ MLB 3040, Ann Arbor, MI 48109, USA \\ aschonle@umich.edu
}

\begin{abstract}
This paper ${ }^{1}$ seeks to evaluate the extent to which Lotman's theoretical works could provide a conceptual articulation to the project of British and American cultural studies (CS). Just as CS, Lotman operates with an extensive concept of culture, albeit one mostly limited to nobility culture and focused on the past. His late works can be seen to articulate a semiotic theory of power: his emphasis on the relationship between center and periphery recalls the infatuation with marginality that underpins CS. Lotman shares the (post) structuralist premise about the primary role of discourse in founding reality. Yet his emphasis on the natural striving of culture toward diversity mitigates the subject's dependence upon discourse. Thus, subjects act on their striving toward autonomy by playing discourses against one another, recoding them in an act of autocommunication that generates novelty in the process.

Even though it denies the grand narrative, Cultural Studies emphasizes class, gender, and race differences. Lotman's concept of the semiosphere emphasizes the ad hoc foundation of group identities, their emergence out of an intrinsic recoding of extrinsic codes, and the circulation of texts and values among groups. Lotman doesn't privilege any sort of group identity and therefore offers a flexible framework applicable to a broader range of groups. In that sense he offers an alternative to Gramsci's notion of the rootedness of groups in class realities (which underlies early CS).
\end{abstract}

Lotman addresses many of the concerns of cultural studies, conceived both narrowly and broadly. Cultural studies emerged partly in respon-

${ }^{1}$ A longer version of this article can be found in the introduction to a collective volume entitled Lotman and Cultural Studies: Encounters and Extensions, ed. by Andreas Schönle, to be published in the United States. I would like to express my gratitude to Helena Goscilo for her generous and invaluable feedback on matters of substance and style. 
se to a single-minded focus on high literature in English Departments, and it rests on a definition of culture as the totality of cultural production, including mass culture in all its variety. Cultural studies has an integrative ambition: it seeks to work out the articulation, i.e. the mutual determinations and interrelations, among the various facets of life - political, economic, social, erotic, and ideological - that make up culture as a whole (Nelson et al. 1992: 14). In order to do so, it not only analyzes an extravagant variety of texts, from fashion and advertising to rock music and graffiti, but also approaches cultural production with an inter-disciplinary, contextualizing method. Lotman shares such an extensive purview, albeit in a different cultural and historical context: ${ }^{2}$ his work on dueling culture, on the semiotics of dress, on aristocratic banquet and food culture, etc., testify to a principled broadening of the traditional notion of culture. Admittedly, he mostly limits himself to the study of nobility culture. Yet he addresses the relationship between high and mass culture theoretically (Lotman 1992a: 209-215) and he exhibits profound interest in folk and traditional culture - he values the specific act of reception presupposed by pre-modern texts and the creative recoding they invite (Lotman 1992b: 243-247). ${ }^{3}$

Cultural studies resists grand theories and meta-discourses that purport to explain everything across historical boundaries. It is contextually specific and strives to be descriptive, although at times it borrows generously from the theories of various contiguous disciplines such as psychoanalysis, sociology, or literary theory (Nelson et al. 1992: 7-8). Lotman's work ranges from the highly specific to the typological and has alternated between theoretical and historically contextual periods, but even his broad cultural typologies serve to undercut the applicability of such master narratives as marxism. In his latest pieces, Lotman repeatedly maintains that crucial binary opposi-

${ }^{2}$ For reasons that will become clear below, cultural studies is primarily devoted to a study of contemporary culture.

${ }^{3}$ Cultural studies and Lotman have both called into question the binary opposition between mass and elite culture. In cultural studies this recognition emerged from the turn to a model of culture as a patchwork of separate communities, each articulating its own differences. See During 1993: 19. Lotman presents mass literature as purely a matter of sociological appreciation, rather than of semiotic structure, and points out the ways in which particular writers have moved in and out of mass literature at various historical junctures. Mass literature is a paradoxical product of a culture that wants to see itself as high (Lotman 1992a: 211-212). 
tions need to be approached historically, rather than a priori, and that there is much to gain from focusing on the gradation between opposites, rather than on a mere logical dichotomy.

The second defining trait of cultural studies is its concern with power. As Tony Bennett puts it, cultural studies is "a term of convenience for a fairly dispersed array of theoretical and political positions, which ... share a commitment to examining cultural practices from the point of view of their intrication with, and within, relations of power" (Bennett 1992: 23). While Lotman is perhaps not as single-minded in his analysis of the nexus between cultural production and power, this collection discusses his conceptualization of the semiotic expression of power. His analysis of the relations between center and periphery echoes the infatuation with the margins of culture in cultural studies. Lotman is acutely aware of the fact that ownership of information confers power, and he discusses the ways in which groups fight for monopoly over information and develop special languages to keep other groups at bay (Lotman 2000a: 395). Even more pointedly, he underscores the intrinsic power (or energy) of signs, their ability to effect changes in their surroundings, so that the deployment of a particular discourse is in itself a form of power (Lotman 2000b: 9).

Two competing paradigms of culture underpin the project of cultural studies: a humanist "culturalist" concept of culture as a whole way of life that can be described empirically and a "(post) structuralist" perspective that posits a web of discourses that determine identity and meaning and that need to be analyzed semiotically or rhetorically. The former view focuses on the experience of subjects who generate their own meanings and adapt social institutions to their own needs. The latter view conceives of the autonomous human subject as an ideological notion peddled by discourse in order to obfuscate the real identity of the subject as an effect of text (Hall 1980: 57-72). This debate, fundamental to cultural studies, has played itself out in various forms, affecting the ways one conceives of hegemony, identity, and resistance. In the United States, cultural studies has tilted heavily towards a "(post) structuralist," i.e. textualist approach, which has diminished its attractiveness to the social sciences. Yet Communication Studies has urged that cultural studies be reoriented toward a critique of American positivism, of the grip of science on social policy, and of the idea of freedom as "our capacity to choose our ends for ourselves" (a kind of individualism that ultimately destroys the public sphere). Such critique would emphasize not the role of texts in determining identity, but that of rituals and institutions 
in constructing forms of social relations and groupings based on a common search for identity, thereby funneling particular "ends" into "taste, style and form of life" consistent with the development of citizenship (Carey 1997: 8, 12).

Lotman's definition of culture as a "bundle" of semiotic systems, that may, but need not be, organized hierarchically (Lotman 2000a: 397), shares the (post) structuralist premise of the primary role of discourse in founding reality. For example, Lotman considers participants in communicative exchanges full-fledged subjects only when they accept a set of restrictions imposed upon them by culture (Lotman 2000c: 562). Yet at the same time, Lotman's emphasis on the natural striving of culture toward diversity (Lotman 2000c: 564), indeed, on the obligatory presence of diversity for a semiotic environment to function properly, mitigates the subject's dependence upon discourse. Thus, subjects act on their impulse to autonomy by playing discourses against one another, recoding them in an act of autocommunication that generates novelty in the process. Thus Lotman grants individuals the capacity to intervene in semiotic systems and thereby affect their cultural environment. In a way, this conception bridges the two paradigms intrinsic to cultural studies. It maintains the discursive nature of reality but empowers the subject to manipulate codes and wrest some measure of autonomy.

The approaches of cultural studies to power have depended upon their primary allegiance to either the "culturalist" or the "(post) structuralist" paradigms. Early approaches tended to glamorize resistance to the hegemonic political center mounted by various social subcultures. The main framework here was the interface between a single political center and oppressed social classes that secured autonomy by elaborating their own counter-cultures. Upon the influx of French sociological and post-structuralist thought, cultural studies ceased to vest the political center with power and, instead, affirmed its decentered nature as a system or grid cast over the entirety of social life and embodied in sociological organization or, even more abstractly, in the discursive underpinnings of reality. Power became so diffuse and surreptitious that the valorization of counter-hegemony collapsed. The interface between state and counter-culture yielded to a much more splintered view of communities organized around a shared identity based on sexuality, gender, or ethnicity. These groups were perceived as striving to develop their own values and ethics and interact with one another on the basis of a multi-culturalist respect for the "other." This embrace of alterity accommodated the valorization of difference, 
but its tendency to reify identity prevented meaningful exchange across communities and often impeded the pursuit of a common political agenda. ${ }^{4}$

Even though it denies a grand narrative, cultural studies emphasizes class, gender, and race differences and cannot help but operate with binary oppositions, despite its stated goal to undercut dichotomies. Lotman's concept of the semiosphere emphasizes the ad hoc foundation of group identities, their emergence out of an intrinsic recoding of extrinsic codes, and the circulation of texts and values among groups. Lotman does not privilege any sort of group identity and therefore offers a flexible framework applicable to a broader range of groups. In this sense, he not only offers an alternative to Gramsci's notion of the rootedness of groups in class realities (which underlies early cultural studies), but also provides an answer to the dilemma between unity and decenteredness in the ways one conceives of the field of culture. For Lotman, culture is essentially both, for it evidences both centrifugal and centripetal forces, which play themselves out on various, coexisting layers (During 1993: 6). Boundaries that cultural agents put up should not lead to a fetishization of what is one's own (svoj) and what is alien (chuzhoj). In addition, Lotman conceives of identity and alterity, that is, of multi-culturalism, as a sphere of engagement rather than of awed respect. His notion of dialogue is one that leads to change, and hence to cultural flux, rather than to social fragmentation.

Auto-communication, as Lotman describes it, resembles what cultural studies calls hybridization, the process by which individuals or communities appropriate external cultural products by investing them with their own functions and meanings (During 1993: 6). At the same time, there are differences of emphasis in the two concepts. In an essay on popular culture, John Fiske theorizes the concept of distance - distance between an individual and the cultural production he consumes - as a key marker of difference between high and low culture (Fiske 1992: 154-165). High culture promotes decontextualized, depoliticized readings of cultural objects because it constructs culture as a sphere of disinterested beauty insulated from social processes. Popular culture, in contrast, is "concretely contextual" (Fiske 1993: 158). It makes cultural objects its own by embedding them in concrete uses, in its practices of living, identifying with them or

${ }^{4}$ On this turning point in cultural studies and its political underpinnings, see During 1993: 11-14. 
deriving sensual pleasure from them without any consideration of appropriate "distance". In short, cultural objects are transposed from the realm of discourse into the sphere of practice. To support his view of the use of culture in everyday life, Fiske quotes ethnographers who write of a "sacred inarticulateness" on the part of respondents who are unable to explain discursively the meaning they invest in particular objects or practices. Thus the meanings that result from hybridization remain opaque to the outside observer, who needs to develop to the greatest extent possible an ability to experience other people's ways of living from the inside (Fiske 1992: 158-159). This conceptualization of counter-hegemony as a non-verbal sphere of practice would be alien to Lotman, who conceives of auto-communication and translation as discursive phenomena and who would endow resisting subjects with much more semiotic creativity than is implicit in such a theory of the everyday. ${ }^{5}$

Auto-communication also offers an alternative to the ways in which cultural studies sought to incorporate marxist ideas. The relationship between cultural studies and marxism is too rich and complex to lend itself to a quick overview. ${ }^{6}$ Yet Stuart Hall's 1983 essay on "The problem of ideology: marxism without guarantees" one of his latest statements on the topic of marxism - speaks to the core of the issue. In a close reading of specific passages from Marx, Hall calls into question the traditional understanding of some of Marx's most seminal concepts. Thus, ideology is no longer a "distortion" of social reality, but a partial view thereof; the link between

${ }^{5}$ Cultural studies has gone through several swings of the pendulum in the way it conceives of the semiotic creativity of the subjects of culture. Both communication studies and ethnography have moved away from a Foucaultian presumption of total passiveness in the face of cultural grids. Communication studies has coalesced onto an "active audience theory" premised on the idea that media texts are necessarily polysemous and that the audience always deflects dominant ideology to its own uses. Ethnography has emphasized micro-analyses and dialogic forms of writing to render the uniqueness of an informant's discourse and the inflections of his (or her) voice in a form unmediated by the analyst's conceptualization. For a critique of the impasse such positions have created, see David Morley 1997. Lotman's notion of double vision, the combination of an intrinsic and extrinsic perspective, as discussed by Mandelker, is consistent with Morley's prescription that it is, in fact, the responsibility of the analyst to propose an account of cultural behavior in terms different from those of his (or her) informants (Morley 1997: 130-131). In Lotman's terms, it is by translating or recodifing cultural discourse that scholarship drives culture forward.

${ }^{6}$ See Larrain 1996 and Sparks 1996. 
economic relations and their ideological representations can no longer be fixed, for language is multireferential (here Hall quotes Voloshinov); the idea of class determination is refined and the direct correspondence between "ruling ideas" and "ruling classes" is replaced with the notion of "tendential alignment" (Hall 1996: 42). Hall seeks to relax the rigid links Marx establishes between ideas and economic relations, but without lapsing into a post-structuralist notion of ideo$\log y$ as a free-floating representation divorced from underlying economic and social realities. ${ }^{7}$ He therefore discusses not so much the structural determination of ideas by the socio-economic base, as the internalization of ideas, the reasons for which certain ideas catch on, while others are consigned to the dustbin of history. And here Hall calls on Gramsci to suggest that "ideas only become effective if they do, in the end, connect with a particular constellation of social forces", i.e. if their "coupling" with the ruling classes is secured (Hall 1992: 4344) ${ }^{8}$ While the nature of this connection is not entirely clear, it seems safe to assume that for Hall, ideologies are successful, i.e. become dominant, when they represent the ruling classe's view of social relations. Underpinning his discussion is the assumption that ideology has referential value, albeit, perhaps, a contested, plural, or ambiguous one. ${ }^{9}$

In his treatment of auto-communication, Lotman shows that when a subject internalizes an extrinsic discourse, the process of recoding weakens, if not entirely suspends, the referential force of language. As a result, ideology's relation to social reality need not be as pertinent or direct as Hall presupposes, and it may therefore serve a more disparate set of groups, not solely social classes. Ideologies become successful, i.e. articulate the identity of a group, because they tie in with, and reinforce, a group's meta-discourses, its discursive memory, despite the

${ }^{7}$ For a retrospective discussion of marxism, which voices concern with the nearly exclusive turn toward the textuality of power in American cultural studies, see Hall 1992: 277-294.

${ }^{8}$ For a critique of cultural studies' lineage in Gramsci's notion of class, see Bennett 1992: 23-37. Bennett calls into question the kind of politics Gramsci's framework promotes when it ignores institutional or group specificities and operates with a notion of "the people" as unified agent.

${ }^{9}$ Starting in the 1980 s, cultural studies abandoned its interest in marxism and, in particular, the notion of determination of ideas through social relations - a move called for in part by the need to address issues of gender and ethnicity in its analysis of contemporary societies. Yet, as a result, cultural studies "is regressing [...] to an essentially textualist account of culture", which differs from literary studies only in the range of texts it considers (Sparks 1996: 98). 
fact that they may come from outside. Ideology, then, has neither a partial, nor distorted, but, rather, an imagined relation to social reality, one that sooner reflects a group's field of discourses, than its social experience.

The third defining trait of cultural studies is its stance of political engagement. Practitioners of cultural studies believe that their discourse matters or should matter (Nelson et al. 1992: 5-7) and they are continuously reflecting on their own institutional location, on the ways their discourse is embedded in institutional reality and contributes to the empowerment of disenfranchised minorities. ${ }^{10}$ Obviously, Lotman could not agitate for his values as explicitly as cultural studies does. Yet, he shares the faith cultural studies has placed in the possibility of affecting its environment through its discursive practice. But the lack of militant rhetoric in Lotman stems not only from tactical prudence, but also from a more principled position as to the function of semiotic meta-discourse and, more broadly, from a faith in the emancipating potential of language. Indeed, the starkest difference between cultural studies and Lotman lies precisely in their respective conceptualization of the relationship between language and power. Cultural studies believes that language participates, wittingly or not, in power imbalances and thus contributes to social oppression, unless the speaker actively calls into question his or her position in a social or cultural field. As a result, cultural studies continuously feels inclined to expose the nexus between power and language, shedding light on this collusion even when language seems not to bear on issues of power. Thus cultural studies has developed a "hermeneutics of suspicion" that is embodied in its rhetoric.

In contrast, Lotman believes that language and art, in particular, add a level of reality to the existing world and thus free us from our entanglement in it. The same can be said of the semiotic metadiscourse, which provides a vantage point that enables us to exert some leverage on the reality in which we feel trapped. Accordingly, the goal of a semiotician, especially one working under totalitarian conditions and the homogenizing pull of the regime, is to expand the ranges of discourses available, so as to empower people to develop more differentiated identities, to enhance their "polyglotism" (Lotman 2000a: 397). Therefore Lotman's "hermeneutics of recovery of

${ }^{10}$ For a useful discussion of the ethical commitment of cultural studies and its difference from Postmodernism, which "undermines the elaboration of an ethic", see Slack, Whitt 1992: 571-592. 
meaning" derives therefore from a commitment to linguistic diversity that requires no militant rhetoric. ${ }^{11}$ The past is a storehouse of discourses that in themselves can serve a liberating function when reinserted in the present. Likewise, the abstract discourse of the semiotician can help wrest us from reality. This conceptual difference between Lotman and cultural studies explains the most obvious disparity between the two: whereby cultural studies seems wedded to the synchronic analysis of contemporary society (partly, to be sure, because of its desire for its discourse to matter politically), Lotman is committed to the restoration of the past and increasingly interested in historical change, both conceptually and contextually.

And it is here that Lotman opens up a perspective that cultural studies seems overly quick to obstruct. Like an obedient Hamlet heeding the injunction of his father's Ghost ("Remember me"), Lotman commits himself to remembrance, rather than vengeance. His responsiveness to the generative powers of literary imagination makes him indifferent to the "hermeneutics of suspicion" for he wants to heed the generative powers of literary imagination. In this regard, he espouses a position that cultural studies may well rejoin, once it thinks through the process of self-reflexive suspicion.

\section{References}

Bennett, Tony 1992. Putting policy into cultural studies. In: Grossberg et al. 1992: 23-37.

Carey, James W. 1997. Reflections on the project of (American) cultural studies. In: Ferguson, Golding, 1997: 1-24.

During, Simon 1993. Introduction. In: During, Simon (ed.), The Cultural Studies Reader. 2nd ed. New York: Routledge, 1-28.

Emerson, Caryl 2000. Bakhtin, Lotman, Vygotsky and Lydia Ginzburg on types of selves: A tribute. In: Engelstein, Laura; Sandler, Stephanie (eds.), Self and Story in Russian History. Ithaca: Cornell University Press, 20-45.

Ferguson, Marjorie; Golding, Peter (eds.) 1997. Cultural Studies in Question. London: Sage Publications.

Fiske, John 1992. Cultural studies and the culture of everyday life. In: Grossberg et al. 1992: 154-173.

${ }^{11}$ Caryl Emerson introduces the opposition between the "hermeneutics of suspicion" (a phrase cointed by Paul Ricoeur) and the "hermeneutics of recovery of meaning" in her essay on the self as conceived by four important Russian thinkers (including Lotman). She discusses the fact that all four thinkers invest the word with an ability to change the environment. See Emerson 2000: 40. 
Grossberg, Lawrence; Nelson, Cary; Treichler, Paula A. (eds.) 1992, Cultural Studies. New York: Routledge.

Hall, Stuart 1980. Cultural studies: Two paradigms. In: Collins, Richard et al. (eds.), Media, Culture and Society, vol. 2. London: Academic Press, 57-72.

- 1992. Cultural studies and its theoretical legacies. In: Grossberg et al. 1992: 277-294.

- 1996. The problem of ideology: Marxism without guarantees. In: Morley, Chen 1996: 25-46.

Larrain, Jorge 1996. Stuart Hall and the marxist concept of ideology. In: Morley, Chen 1996: 47-70.

Lotman, Juri 1992a. O soderzhanii struktury i poniatiya 'hudozhestvennaya literatura'. In: Lotman, Juri, Izbrannye trudy, vol. 1. Tallinn: Aleksandra, 203-215.

- 1992b. Kanonicheskoe iskusstvo kak informatsionnyi paradoks. In: Lotman, Juri, Izbrannye trudy, vol. 1. Tallinn: Aleksandra, 243-47.

- 2000a. Stat'i po tipologii kul'tury. In: Lotman, Juri, Semiosfera. St. Petersburg: Iskusstvo-SPB, 391-459.

- 2000b. Liudi i znaki. In: Lotman, Juri, Semiosfera. St. Petersburg: IskusstvoSPB, 5-10.

- 2000c. Kul'tura kak kollektivnyi intellekt i problemy iskusstvennogo razuma. In: Lotman, Juri, Semiosfera. St. Petersburg: Iskusstvo-SPB, 557-567.

Morley, David 1997. Theoretical orthodoxies: Textualism, constructivism and the 'new ethnography' in cultural studies. In: Ferguson, Golding 1997: 121-137.

Morley, David; Chen, Kuan-Hsing (eds.) 1996. Stuart Hall: Critical Dialogues in Cultural Studies. London: Routledge.

Nelson, Cary; Treichler, Paula A.; Grossberg, Lawrence 1992. Cultural studies: An introduction. In: Grossberg et al. 1992: 1-16.

Slack, Jennifer Daryl; Whitt, Laurie Anne 1992. Ethics and cultural studies. In: Grossberg et al. 1992: 571-592.

Sparks, Colin 1996. Stuart Hall, cultural studies and marxism. In: Morley, Chen 1996: 71-101.

\section{Юрий Лотман и Cultural Studies: возможности взаимного обогашения}

Цель статьи - определить, до какой степени теоретические работы Лотмана могли бы стать некоторой концептуальной основой для проекта американских и британских Cultural Studies (CS). Подобно CS, Лотман оперирует широким пониманием культуры, хотя он в основном ограничивает себя исследованием дворянской культуры. Его поздние работы выдвигают своего рода семиотическую теорию власти. Его анализ соотношения между центром и периферией напоминает присущую CS установку на маргинальность. Лотман разделяет (пост)структуралистскую предпосылку о первичной роли дискурса в обосновании реальности. Вместе с тем, его представление о естественном стремлении 
культуры к разнообразию смягчает зависимость субъекта от дискурса. Путем разыгрывания разных дискурсов между собой и их перекодировки в акте автокоммуникации субъекты могут добиться некоторой автономности и создать новые значения.

Несмотря на то, что CS отказываются от сверхнарративов, оно делает установку на классовые, гендерные и расовые различия. Лотмановское понимание семиосферы акцентирует ситуативную основу групповых идентичностей, их возникновение из перекодировки существующих дискурсов. Лотман не оказывает предпочтения определенному типу идентичности. Он предлагает более гибкий подход, который применяется к широкому и меняющемуся разряду социальных групп. Таким образом его теория представляет собой альтернативу концепции Грамши (лежащей в основе CS) об укоренности групп в классовых отношениях.

Автокоммуникация имеет сходство с тем, что в CS называют гибридизацией, т.е. процессом освоения внешних культурных объектов, при котором этим объектам приписывается индивидуальное значение. Вместе с тем, существует разница между этими понятиями. Для CS сопротивление преобладающей власти происходит в основном на уровне невербального быта, в то время как для Лотмана автокоммуникация и перевод между разными семиотическими системами имеет место на дискурсивном уровне, что предоставляет субъекту некоторую творческую инициативу.

CS - это форма политической ангажированности. Лотман разделяет установку CS на трансформацию окружающей среды речевым поведением. Отсутствие политически окрашеннего языка у Лотмана объясняется не только необходимой при советской власти тактической осторожностью, но и принципиальным положением о функции семиотического метадискурса. Если CS склонны к постоянному разоблачению причастности языка к социальной несправедливости, то Лотман верит в способность языка обосновать добавочный уровень действительности, с помощью которого человек может выйти из вовлеченности в мир. Таким образом, лотмановское стремление восстановить культуру прошлого и есть освободительный проект.

\section{Juri Lotman ja Cultural Studies: vastastikuse rikastamise võimalused}

Artikli eesmärgiks on määratleda, mil määral Lotmani teoreetilised tööd võisid olla teatud kontseptuaalseks aluseks ameerika ja briti Cultural Studies (CS) jaoks. Nagu ka CS, opereerib Lotman kultuuri laia mõistega, kuigi piirdub põhiliselt aadlikultuuri uurimisega. Tema hilisemad tööd esitavad oma- 
laadse semiootilise võimuteooria, kus keskuse ja perifeeria vahelise suhte analüüs meenutab CS omast suunitlust marginaalsusele. Lotman jagab (post)strukturalistlikku eeldust diskursuse esmasest rollist reaalsuse põhistamisel. Samal ajal pehmendab tema ettekujutus kultuuri loomulikust püüdest eripalgelisusele subjekti sõltuvust diskursusest. Mängides erinevaid diskursusi omavahel läbi ja neid autokommunikatsiooni aktis ümber kodeerides võivad subjektid saavutada teatud autonoomsuse ja luua uusi tähendusi.

Vaatamata sellele, et CS loobub ülinarratiividest, teeb ta panuse klassilistele, soolistele ja rassilistele erinevustele. Lotmani arusaam semiosfäärist rõhutab grupiliste identsuste situatiivset alust, nende tekkimist olemasolevate diskursuste ümberkodeerimise tulemusena. Lotman ei eelista teatud identsuse tüïpi. Ta pakub paindlikumat lähenemist, mida kasutatakse sotsiaalsete gruppide laia ja muutuva liigituse puhul. Seega kujutab tema teooria endast alternatiivi Gramsci kontseptsioonile gruppide juurdumisest klassisuhetes, mis on CS aluseks.

Autokommunikatsioon sarnaneb sellega, mida CS nimetab hübridisatsioon, st väliste kultuuriliste objektide omandamise protsess, mille puhul nendele objektidele omistatakse individuaalne tähendus. Samal ajal on ka erinevus nende mõistete vahel. CS jaoks toimub valitsevale võimule vastuhakk peamiselt mitteverbaalse olme tasandil, samal ajal kui Lotmani jaoks leiavad autokommunikatsioon ja tõlge erinevate semiootiliste süsteemide vahel aset diskursiivsel tasandil, mis jätab subjektile teatud loomingulise initsiatiivi.

CS on poliitilise angažeerituse vorm. Lotman jagab CS vaadet, et kõneline käitumine kujundab ümber ümbritseva keskkonna. Poliitilise värvinguga keele puudumine Lotmanil on seletatav mitte ainult nõukogude võimu ajal hädavajaliku taktikalise ettevaatusega, vaid ka põhimõttelise seisukohaga semiootilise metadiskursuse olemuse kohta. Kui CS kaldub pidevale keele osaluse paljastamisse sotsiaalses ebaõigluses, siis Lotman usub keele võimesse põhistada tegelikkuse lisatasand, mille abil inimene võib väljuda hõlmatusest maailma. Seega on Lotmani püüd taastada mineviku kultuur omalaadne vabastav projekt. 